\title{
MULTINATIONAL MARKETING
}

\author{
door Prof. Dr.J. L. Bouma en Drs. J. C. Reuijl
}

\section{Inleiding}

De ernstige ontwrichting van het economische leven als gevolg van de tweede wereldoorlog heeft voor vele landen de noodzaak meegebracht een politiek van isolationisme te verwisselen voor een politiek van internationale samenwerking. Om een enkel voorbeeld te noemen. Europa kreeg zijn E.E.G., E.F.T.A. en COMECON. In het Midden Oosten ontstond de Arab Common Market en de Re gional Cooperative for Development. Afrikaanse landen verenigden zich tot o.a. de East Africa Custom Union, de Maghreb Economic Community en in Latijns Amerika ontwikkelde zich de Central American Common Market en de Latin American Free Trade Association. Deze versterkte neiging tot samenwerking heeft geleid tot het ontstaan van een mondiaal handelspatroon, dat moeilijk meer vergelijkbaar is met dat van de jaren vlak na de tweede wereldoorlog, laat staan met het vooroorlogse patroon.

Voor individuele organisaties is daardoor een scala van mogelijkheden ont staan om de marketing activiteiten uit te breiden naar andere landen. Vanuit marketing-oogpunt is de vraag van belang in hoeverre het bewerken van mark. ten in meerdere landen consequenties heeft voor het vaststellen van het marketing-beleid. Of anders gesteld: zijn er verschillen aan te geven tussen mononationale marketing, kortweg aan te duiden als monomarketing en multinationale marketing? Wij zullen dit nagaan door beide begrippen te definiëren.

De inhoudelijke betekenis die wij aan marketing geven, impliceert dat multinationale marketing niet gezien kan worden als een marginale activiteit, waarvoor binnen de organisatie slechts belangstelling ontstaat, indien zich op de thuis. markt afzetproblemen voordoen. Multinationale marketing dient ook niet te wor. den vereenzelvigd met het traditionele begrip export. Bij de overgang van mo. nomarketing naar multinationale marketing staan een organisatie meerdere mogelijkheden ter beschikking, waarvan export er één is. Een aantal alternatieven zullen wij aan de orde stellen.

Het doen van een keuze uit deze alternatieven is slechts mogelijk, indien de or ganisatie haar uitgangspunten heeft bepaald met betrekking tot de internationalisering van de marketing activiteiten. In dit opzicht zijn meerdere mogelijkheden aanwezig. Vanuit het gekozen uitgangspunt kunnen de potentiële buitenlandse markten worden geselecteerd. Wij zijn van mening dat dit selectieproces verschillende fasen dient te omvatten. In eerste instantie zal aan de hand van een globale analyse uitgemaakt moeten worden, welke landen in principe in aanmerking ko. men voor bewerking. Teneinde te toetsen inhoeverre de voorlopige keuze juist is geweest, dient men ieder der geselecteerde landen daarna te onderwerpen aan een gedetailleerde analyse, die zich toespitst op de omgevingsaspecten.

Structuurverschillen in de omgeving zullen veelal aanpassingen in de te han. teren marktinstrumenten noodzakelijk maken. Ieder marktinstrument kent daarbij zijn eigen problematiek. Wij zullen ingaan op de problemen, die men ontmoet bij de produkt., de prijs, de reclame- en de distributiepolitiek').

\footnotetext{
1) Wij spreken van reclame. Figenlijk zou gesproken moeten worden van promotion, dat naast reclame ook nog persoonlijke verkoop, publiciteit en sales promotion omvat. Wij beperken ons evenwel tot reclame.
} 
Bij een partiële beschouwing van de marktinstrumenten wordt geen aandacht geschonken aan de interactie tussen de marktinstrumenten. Wij zullen evenwel niet voorbij kunnen gaan aan de problematiek van de marketing mix, d.w.z. het samenstel van marktinstrumenten dat op een bepaalde markt wordt ingezet. Daaraan zijn twee hoofdaspecten verbonden. In de eerste plaats moet worden vastgesteld, in hoeverre de mix zal worden aangepast aan lokale omstandigheden. Daarnaast dient men een beslissing te nemen over de allocatie van de mid delen aan de marketing mix voor de verschillende landen. Deze toewijzing is slechts mogelijk, indien de marketing beslissingen worden gecoördineerd met de beslissingen in de andere functionele gebieden binnen de organisatie. Dit betekent dat wij het marketing management in relatie moeten brengen met het financiële en produktiemanagement.

\section{Marketing, monomarketing en multinationale marketing}

Het begrip "marketing" is in de literatuur op talrijke en verschillende wijzen gedefinieerd. Wij willen ten behoeve van onze uiteenzetting niet proberen nog een nieuwe definitie te ontwikkelen doch ons aansluiten bij Kotler ${ }^{-}$. Kotler omschrijft marketing als volgt: „The core concept of marketing is the transaction. A trans. action is the exchange of values between two parties... Marketing is specifically concerned with how transactions are created, stimulated, facilitated and valued". "The exchange of values" kan worden betrokken op een grote verscheidenheid van ruilverschijnselen. Niet alleen op de ruil van goederen tegen geld, doch ook bijvoorbeeld op de ruil van kiesrechtelijke stemmen voor politieke beloften en illusies, of op de ruil van gehoorzaamheid voor later zieleheil.

De marketing als ondernemingsactiviteit omvat de stroomlijning van ruiltransacties, zowel naar binnen als naar buiten. Binnen de organisatie zoekt de marke. ting de coördinatie met andere functionele gebieden als produktie en financiering. Men zou hier kunnen spreken van „exchange of values” tussen de marketingfunctie en de ,interne omgeving" en de afstemming der plannen inzet is van dit „ruilproces”.

In het kader van onze uiteenzetting over multinationale marketing is de externe oriëntatie van de marketing van overwegend belang. De onderneming ruilt met haar omgeving „waarden”. Het is dus voor de onderneming noodzakelijk te weten wat haar omgeving als "waarden” ziet en welke van die „waarden” door haar (de onderneming) kunnen worden geleverd. Het waardenstelsel van de omgeving wordt door diverse factoren bepaald, zoals de concurrentie structuur, politieke, sociale, economische en juridische instituten, voorschriften en gebruiken, alsmede verschillende facetten van het consumentengedrag. Het succes van de voorgenomen ruiltransacties berust enerzijds op de nauwkeurigheid van de ken. nis omtrent de opvattingen van de afnemers inzake de door hen relevant geachte produkteigenschappen (,dimensies”; waarden) en anderzijds op de fijnzinnigheid en doeltreffendheid waarmee de onderneming aan haar afnemers weet duidelijk te maken dat zij bij uitstek in staat is de gezochte waarden te leveren. Aangezien verwacht mag worden dat het waardenpatroon aan verandering onderhevig is,

P. Kotler. A Generic Concept of Marketing, Journal of Marketing, April, 1972, Pp. 48 en 49.

) P. A. Beukenkamp en P. S. H. Leefiang, Probleemgebied marketing: epn managementbenadiring Interfaculteit Bedrijfskunde, Delft/Rotterdam 2.j., pp. 10 e.v. 
zal het onderzoek van en de berichtgeving aan de omgeving een min of meer continu karakter moeten hebben.

Is de voor de omgeving relevante omgeving uniform en homogeen dan kan men spreken van één (afzet)markt en kan men de marketing typeren als mono marketing. De relevante omgeving kan evenwel zodanig zijn gekozen dat de uniformiteit en homogeniteit plaats maken voor pluriformiteit en heterogeniteit. De verscheidenheid in de omgeving leidt tot verscheidenheid in markten en derhal. ve tot pluriforme marketing. Indien de verschillen in de omgeving voornamelijk zijn terug te voeren op verschillen in culturele en sociale gedragspatronen, die op hun beurt samenhangen met of bepaald worden door geografische en ethnografische factoren respectievelijk staatsrechtelijke grenzen, dan heeft de pluriforme marketing het karakter van ,international marketing” of te wel multinationale marketing. Miracle en Albaum geven de volgende definitie: „International marketing management includes the management of marketing activities for products which cross the political boundaries of sovereign states. It also includes marketing activities of firms which produce and sell within a given foreign nation if certain conditions are met: (1) if the firm is a part of an organization or enter. prise which operates in other countries and (2) if there is some degree of influence, guidance, direction, or control of such marketing activities from outside the country in which the firm produces and sells the product". $)$

De verschillen tussen mono-marketing en multinationale marketing zijn gra dueel. Men dient dus behalve voor de verschillen ook een open oog te blijven hou den voor de overeenkomst tussen de onderscheiden markten.

\section{De concrete inhoud van multinationale marketing}

Voor het uitbreiden van de marketing activiteiten naar buitenlandse markten staan een organisatie meerdere alternatieven ter beschikking. Een eerste moge lijkheid is export. Indien en voorzover de export niet het karakter heeft van het bij tijd en wijle afstoten van produktieoverschotten, doch veeleer een zekere con. tinuiteit in de marktrelatie beoogt, dan kan export worden gezien als een variant die, in vergelijking tot andere vormen van multinationale marketing, het voor. deel heeft van risico-reductie. Immers omvangrijke investeringen in het buiten. land kunnen worden vermeden. Daar staat tegenover, dat de voeling met de markt geringer kan zijn. In welke mate dat het geval is, hangt in de eerste plaats af van het feit of het om industriële of consumptiegoederen gaat. Bij industriële goederen zal het marktcontact over het algemeen beter zijn. Daarnaast van de wijze waarop de export geschiedt. In dit opzicht dient onderscheid te worden gemaakt tussen indirecte en directe export $)$. Van indirecte export is sprake indien de buitenlandse afzet wordt gerealiseerd via de exporterende groothandel of de ex portagent. Bij directe export verkoopt de organisatie direct aan een agent of de im porterende groothandel in het exportland of aan een eigen verkoopkantoor. Het zal duidelijk zijn dat met name bij indirecte export het gevaar voor gemis aan marktinzicht niet denkbeeldig is.

\footnotetext{
4) G. En Miracle en G. S. Albaum, International Marketing Management, Irwin, Inc., Homewood, Illinois, 1970, p. 5; Miracle en Albaum spreken van ,intermational marketing". Wij prefereren de term multinationale marketing.

5) Zie voor een uitvoerige beschouwing over dit onderwerp: B. A. Bakker, Facetten van export marketing, Intermediair. 17 ja nuari, 1975, pp. 27 e.v.
} 
De investeringen in het buitenland zullen ook beperkt kunnen worden, indien de organisatie voor door haar gepatenteerde produkten een licentie-overeenkomst aangaat. Het bewerken van buitenlandse markten via licentiecontracten kan een doelbewuste strategie zijn, ingegeven door de gedachte dat bij een zorgvuldige selectie van de licentiehouders op vrij korte termijn een mondiale spreiding van het gepatenteerde produkt wordt verkregen. Over het algemeen zullen de licentiehouders namelijk reeds beschikken over een produktie- en verkooporganisatie. Daarnaast biedt het licentiecontract mogelijkheden voor landen, waarvoor importrestricties gelden of waar de nationale overheid de penetratie van buitenlandse organisaties tegenwerkt.

In het laatste geval is de mogelijkheid aanwezig dat de licentie-overeenkomst wordt gezien als een voorlopige keuze, die op een later tijdstip wordt gevolgd door een andere vorm van multinationale marketing. Voor de hand liggend is het bijv. dat licentiegever en houder reeds bij de opstelling van de overeenkomst de mogelijkheid open laten van een joint venture, een samenwerkingsvorm waarbij twee of meer zelfstandige organisaties een inbreng hebben in een nieuw op te richten organisatie.

De betekenis van de joint venture is de laatste decennia sterk toegenomen en het is te verwachten, dat deze trend zich in de toekomst voortzet. Met name bij het betreden van markten in ontwikkelingslanden biedt de joint venture de mogelijkheid om tot een compromis te komen tussen de tegengestelde belangen van de penetrerende organisatie en de nationale overheid. Wij onderschrijven de me. ning van Wright, dat de realisatie van een dergelijk compromis slechts mogelijk is vanuit een , joint venture space": „It is useful to conceive of a joint venture space, the dimensions of which are the key variables: control, risk and skills transfer. It should be noted that the host nation and the corporation have traditionally held differing perceptions of joint venture space. From the host nation's point of view, joint venture space is perceived as a simple control/skills transfer plane. The corporation, on the other hand, views its activity on a risk/control plane. It is a fun. damental contention of this paper that international collaborative arrangements in the developing nations must be viewed by both parties within the full three dimensional joint venture space if mutually beneficial arrangements are to be found". $\%$.

Een specifieke vorm van een joint venture vormt management contracting, waarbij de inbreng van de multinationale organisatie zich beperkt tot de inbreng van management en know how. Deze beperkte inbreng kan gepland zijn als een start. punt voor een meer omvattende deelname, het kan ook de laatste fase zijn van een buitenlandse expeditie, bijv. bij nationalisatie van een vestiging door een vreemde overheid.

Het meest vergaand ten slotte is het stichten van een buitenlandse vestiging met een eigen produktie. en verkooporganisatie. De keuze van dit alternatief kan o.a. ingegeven zijn door besparingen in de transportkosten, door verschillen in loonkosten, door hoge invoerrechten en een streven naar een intensief marktcontact. Daar staat een aanzienlijke vergroting van het risico tegenover, omdat omvang. rijke investeringen verricht moeten worden.

\footnotetext{
b) R. W. Wright, Multinational Corporate Strategies in Developing Countries, in R. N. Farmer (ed.), Multunational Firm Strategies, Volume I. Indiana University, Bloomington, Indiana. 1975, p. 111
} 
In de literatuur ontmoet men nogal eens de opvatting, dat de hiervoren be schreven varianten sequentieel geordend zouden kunnen worden en wel als volgt:

export $\rightarrow$ licentie $\rightarrow$ joint venture $\rightarrow$ buitenlandse vestiging

Deze ordening is waarschijnlijk gebaseerd op de mate van risico, die aan de ver. schillende varianten is verbonden. Ons inziens getuigt deze rangschikking van een hoogst onvolledige interpretatie van het begrip multinationale marketing. Het behoeft geenszins zo te zijn dat een organisatie die voornemens is meerdere bui. tenlandse markten te gaan bewerken, voor iedere afzonderlijke markt export als enige alternatief in beschouwing neemt. De keuze van de variant hangt af van de structuur van de verschillende markten en van de uitgangspunten die de or ganisatie ten aanzien van multinationale marketing heeft gekozen.

\section{Het definiëren van uitgangspunten voor multinationale marketing}

Zoals wij reeds stelden, kan een beslissing tot het verleggen van de marketingac. tiviteiten naar het buitenland niet op ad hoc-basis worden genomen. Zowel het selecteren van de markten als de keuze van de variant van multinationale marketing zal gebaseerd moeten zijn op een min of meer continu en consistent beleid. Dat brengt voor de organisatie de noodzaak mee om vooraf algemene uitgangs punten met betrekking tot multinationale marketing te ontwikkelen. Daarbij zijn vele mogelijkheden voorhanden. Wind, Douglas en Perlmutter classificeren de verschillende mogelijke uitgangspunten aan de hand van een viertal begrippen: ethnocentrisme, polycentrisme, regiocentrisme en geocentrisme. ${ }^{7}$ )

Een organisatie die ethnocentrisch ${ }^{\text {ia) }}$ is georiënteerd, ziet naar de opvatting van de genoemde auteurs de thuismarkt als primair. Aan systematisch onderzoek van buitenlandse markten wordt geen of nauwelijks aandacht besteed. Over het al. gemeen zal er een geringe bereidheid aanwezig zijn om modificaties aan te brengen in het produkt en de reclame. Als vorm van multinationale marketing wordt meestal gekozen voor indirecte export.

Van polycentrisme is sprake, indien als uitgangshypothese voor multinationale marketing geldt dat iedere markt uniek is. De keuze van dit uitgangspunt brengt de noodzaak mee van een zorgvuldig onderzoek naar specifieke kenmerken van markten en het zonodig doorvoeren van aanpassingen in de marketing mix. In deze benadering vinden wij het door ons bepleite marketing georiënteerde denken volledig terug. In extremis echter kan het polycentrisme leiden tot een unieke marketing mix per markt. Zulks impliceert een aanzienlijke verzwaring van het coördinatieprobleem.

Deze coördinatieproblematiek wordt voor een deel gereduceerd, indien het uitgangspunt van de organisatie regiocentrisch gericht is. In deze gedachtengang wordt ervan uitgegaan, dat er weliswaar verschillen tussen markten kunnen bestaan, doch dat het desondanks mogelijk is in de vorm van regio's segmenten te definiëren, waarvoor gelijke marketingstrategieën kunnen worden ontwikkeld. Deze regio's lopen dan over de landsgrenzen heen. Nog een stap verder gaat men door het kiezen van een geocentrisch uitgangspunt, waarbij de ontwikkeling van een mondiaal geldende standaardstrategie mogelijk wordt geacht.

\footnotetext{
7) Y. Wind, Susan P. Douglas, H. V. Perlmutter, Guidelines for Developing International Marketing Strategies, Journal of Mar keting, April 1973, pp. 14.23.

a) Wellicht ware de term "monocentrisch" hier beter op zijn plaats.
} 
Op de vraag of aan één van de genoemde uitgangspunten de voorkeur is te geven is in zijn algemeenheid geen antwoord te geven. Wel is het voor een in. dividuele organisatie mogelijk een voorkeursordening aan te geven. Dat kan ge. schieden vanuit drie criteria:

a) de aard van het door de organisatie voortgebrachte produkt;

b) de absolute en relatieve omvang van de potentiële markten voor dat produkt; c) de mate van heterogeniteit van de potentiële markten.

Duidelijk is, dat deze criteria in onderlinge samenhang moeten worden be schouwd. Het is zeer wel mogelijk dat op grond van de aard van het produkt een polycentrische benadering voor de hand ligt, terwijl desondanks een ethnocen. trisch uitgangspunt wordt gekozen vanwege de omvang van de potentiële markt.

Uit ons betoog mag niet worden afgeleid dat er met betrekking tot het defi. niëren van een algemeen uitgangspunt toch een zekere produktgebondenheid bestaat en dat het bestaan van een uitgangspunt voor de organisatie als geheel betwijfeld moet worden. Wij hebben een specifieke situatie beschreven, namelijk een organisatie die voor een reeds bestaand produkt buitenlandse afzetmarkten zoekt. Het omgekeerde, een organisatie die op grond van het voor de organisatie geldende uitgangspunt naar produkten zoekt, is evenzeer denkbaar en - gezien de trend naar diversificatie - misschien zelfs meer in overeenstemming met de werkelijkheid.

In de door Wind, Douglas en Perlmutter gegeven classificatie staat het criterium van de overeenkomst (similarity) tussen de potentiële markten centraal. Daarnaast is echter nog een ander relevant aspect te noemen, namelijk de afweging tussen concentratie en meervoudigheid (multiplicity) en wel op grond van de ook bij multinationale marketing geldende $80.20 \%$ regel. Combineren wij beide aspecten, dan kan vanuit het gekozen uitgangspunt een strategie worden ontwikkeld. Doyle en Gidengil onderscheiden in dit verband vier mogelijke strategieën: ${ }^{8}$ )

a) geconcentreerde gelijksoortigheid: de organisatie concentreert zich op het bewerken van een gering aantal gelijksoortige markten;

b) geconcentreerde verscheidenheid: de organisatie kiest een gering aantal markten, die een verschillende structuur hebben;

c) meervoudige gelijksoortigheid: de organisatie bewerkt een groot aantal markten met gemeenschappelijke kenmerken;

d) meervoudige verscheidenheid: de inspanningen van de organisatie zijn gericht op een groot aantal markten, die een gering aantal gemeenschappelijke karak. teristieken bezitten.

\section{Het selecteren van markten}

De door de organisatie gekozen strategie met betrekking tot multinationale marketing vormt een bruikbaar uitgangspunt voor het selecteren van toekomstige markten. Naar onze opvatting dient dit selectieproces in fasen te verlopen. In eerste instantie zal aan de hand van een globale analyse moeten worden bepaald, welke landen in principe in aanmerking komen voor bewerking. Vervolgens dient deze voorlopige keuze te worden getoetst door ieder der geselecteerde lan-

ð) P. Doyle, Z. B. Gidengil, A Strategic Approach to Intemational Market Selection, Sixth Annual Workshop on Research in Marketing, Saarbrücken, 1977 , p. VII 4. 
den te onderwerpen aan een gedetailleerde analyse, die zich toespitst op de omgevingsaspecten.

\subsection{De voorlopige selectie van markten}

$\mathrm{Bij}$ veel organisaties heeft het in het verleden ontbroken aan een systematische procedure voor het selecteren van potentiële markten. De uitbreiding van de marketingactiviteiten naar nieuwe landen droeg vaak een min of meer inciden. teel karakter, met als gevolg dat er sequentieel gezien weinig consistentie in het selectieproces te bespeuren is. Deze consistentie is slechts te realiseren, indien aan het kiezen van potentiële markten een planningsprocedure ten grondslag ligt, waarbij de samenhang tussen de verschillende markten in aanmerking wordt genomen. Wij zullen trachten aan te geven, hoe men zich de uitwerking van een dergelijke procedure dient voor te stellen.

In de eerste plaats zal het - onafhankelijk van de gekozen strategie - wenselijk zijn om na te gaan of er, mondiaal bezien, groepen van landen zijn aan te wijzen, die een zekere mate van overeenkomst vertonen. Daartoe zou aan de hand van bepaalde indicatoren een clusteranalyse uitgevoerd kunnen worden. ${ }^{9}$ ) Mogelijke indicatoren zijn bijv:

- demografische factoren, zoals de totale bevolking, de bevolkingsgroei, de leef. tijdsopbouw van de bevolking, de mate van urbanisatie;

- geografische factoren, zoals de oppervlakte van een land, de bevolkingsdichtheid;

- economische factoren, zoals het bruto nationaal produkt, de investeringsratio, de inkomensverdeling;

- technologische factoren, zoals het energieverbruik per hoofd, het peil van de technologische ontwikkeling;

- socio-culturele factoren, zoals de mate van culturele homogeniteit, „life style”. patronen;

- de mate van produktgebruik.

Blijkt het mogelijk clusters te ontdekken, dan zal getracht moeten worden daar. in een bepaalde rangordening aan te brengen. Dit om de volgorde aan te geven, waarin de clusters in beschouwing zullen worden genomen. Daartoe zal men een ordeningscriterium dienen te vinden. Dat zou bijv. het marktpotentieel van een cluster kunnen zijn. Het vinden van een operationele maatstaf voor de bepaling van het marktpotentieel is echter een alles behalve eenvoudige opgave. Douglas, Le Maire en Wind stellen daarom voor om voor de schatting van dit potentieel uit te gaan van intermediërende variabelen, zoals de hiervoren aangegeven indicatoren $\left.{ }^{10}\right) \mathrm{Wij}$ zouden deze suggestie willen overnemen, met dien verstande dat voor ons doel (de schatting van het potentieel van een cluster) alleen die variabelen in aanmerking komen die de mogelijkheid tot aggregatie bieden.

Is het potentieel van de clusters aldus vastgesteld, dan staan verschillende we. gen open. Welke weg wordt gekozen, hangt af van de strategie die van te voren is vastgesteld. Voor een organisatie die bijv. een strategie van geconcentreerde gelijksoortigheid als uitgangspunt heeft gekozen, komen de laagst geordende clus ters waarschijnlijk niet in aanmerking, omdat het marktpotentieel niet voldoende

\footnotetext{
9) Zie bijv. P. Doyle, Z. B. Gidengil, op. cit

${ }^{10}$ S Susan Douglas, P. Le Maire, Y. Wind, Selection of Global Target Markets: a Decision Theoretic Approach, Marketing in a Changing World, Esomar. 1972, p. 245.
} 
is. $\left.{ }^{11}\right)$ Heeft men echter gekozen voor meervoudige verscheidenheid, dan komen in principe alle clusters in aanmerking, omdat zich binnen een cluster individuele landen met voldoende marktpotentieel kunnen bevinden.

De - afhankelijk van de gekozen strategie - geselecteerde clusters ondergaan nu een voortgaande screening. Dit kan geschieden aan de hand van een evaluatie per land. Daartoe zullen factoren gedefinieerd moeten worden die een vergelijking tussen de landen mogelijk maken. Daarvoor komen in de eerste plaats de reeds genoemde intermediërende variabelen in aanmerking. Andere mogelijke factoren zouden kunnen zijn: de mate van importbeperking, de politieke stabili. teit, de neiging tot nationalisatie.

Uitgaande van de factoren die als criterium zullen dienen, zijn er ons inziens twee methoden die het selecteren en rangordenen van de landen binnen een cluster mogelijk maken.

1. De gewogen factorscore methode, waarbij iedere factor wordt beschreven op bijv. een vijf-puntsschaal, die varieert van zeer goed tot zeer slecht. Bij elke schaalwaarde behoort een schaalniveau met een overeenkomende beschrijving, bijv.:

- factor: importbeperking;

- beschrijving: er bestaan voor het betreffende land geen invoerbeperkingen;

- schaalniveau: zeer goed;

- schaalwaarde: 5 .

Vervolgens dient voor iedere factor de kans bepaald te worden, dat een schaal. niveau wordt bereikt. De verwachte schaalwaarde van een factor is dan:

$\mathrm{E}\left(\mathrm{SF}_{\mathrm{i}}\right)=\sum_{\mathrm{j}} \mathrm{p}_{\mathrm{ij}} \mathrm{S}_{\mathrm{j}} \quad\left(0 \leqslant \mathrm{p}_{\mathrm{ij}} \leqslant 1, \quad \sum_{\mathrm{j}} \mathrm{p}_{\mathrm{ij}}=1\right)$

waarin:

$\mathrm{S}_{\mathrm{j}} \quad=$ de schaalwaarden;

$\mathrm{p}_{\mathrm{ij}} \quad=$ de kans dat schaalwaarde $\mathrm{S}_{\mathrm{j}}$ wordt bereikt door factor $\mathrm{i}$;

$\mathrm{E}\left(\mathrm{SF}_{\mathrm{i}}\right)=$ de verwachte schaalwaarde van factor $\mathrm{i}$.

Kennen wij bovendien aan iedere factor een gewicht toe, dat de betekenis van deze factor weerspiegelt binnen het kader van de gehanteerde strategie, dan kan de verwachte bijdrage van iedere factor worden vastgesteld.

$\mathrm{E}\left(\mathrm{B}_{\mathrm{i}}\right)=\mathrm{g}_{\mathrm{i}} \cdot \mathrm{E}\left(\mathrm{SF}_{\mathrm{i}}\right) \quad\left(0 \leqslant \mathrm{~g}_{\mathrm{i}} \leqslant 1 ; \quad \sum_{\mathrm{i}} \mathrm{g}_{\mathrm{i}}=1\right)$

waarin:

$\mathrm{E}\left(\mathrm{B}_{\mathrm{i}}\right)=$ de verwachte bijdrage van factor $\mathrm{i}$;

$\mathrm{g}_{\mathrm{i}} \quad=$ het gewicht van factor $\mathrm{i}$.

Sommering van de verwachte bijdrage over alle factoren leidt ten slotte tot de verwachte score van een land. Deze score kan worden vergeleken met een aspiratieniveau, waarna de beslissing over het al dan niet laten afvallen van een land genomen kan wordern. Bovendien is het mogelijk de overgebleven landen binnen een cluster te rangordenen aan de hand van verwachte scores.

2. Het selecteren van landen op globale basis kan ook worden gerealiseerd via een hierarchieke voorkeursordening methode. Daarbij gaat men als volgt te werk:

a) rangschik de factoren in volgorde van belangrijkheid;

b) bepaal per factor een aspiratieniveau tussen 0 en 1 waaraan een land moet voldoen alvorens voor voortgaande beschouwing in aanmerking te komen;

\footnotetext{
11, Het al of niet voldoende zijn van een bepaalde doelvariabele kan nader worden uitgewerkt met behulp van een satisfactor theorie.
} 
c) relateer de score van ieder land aan het aspiratieniveau van de meest belang. rijke factor en laat ieder land afvallen dat niet voldoet aan dit aspiratieniveau;

d) doe hetzelfde voor iedere volgende factor;

e) kies die landen, waarvan de score voor iedere factor voldoet aan het aspira tieniveau.

Wij zijn ons ervan bewust, dat aan de door ons voorgestelde methoden bepaalde bezwaren kleven. Daar staat echter tegenover dat ze beide de mogelijkheid bieden het selectieproces te baseren op een onderlinge vergelijking van landen. Bo vendien dat de selectie door het hanteren van factorgewichten geschiedt vanuit een ex ante vastgestelde strategie.

\subsection{De definitieve selectie van markten}

Zoals wij reeds meermalen hebben gesteld, kan het bedrijven van multinationale marketing alleen dan succesvol zijn, indien daaraan diepgaande kennis van de omgeving ten grondslag ligt. Een ,exchange of values” is namelijk alleen dan mogelijk, wanneer er sprake is van een onderlinge afstemming van de motieven en verlangens van de organisatie, de consumenten en de andere participanten uit de omgeving. Dat betekent dat een organisatie de definitieve beslissing tot het bewerken van een nieuwe markt nimmer mag baseren op een globale analyse, waarbij in hoofdzaak gebruik is gemaakt van secundaire gegevens. Er zal aanvullend marktonderzoek verricht moeten worden, waaraan primaire data over de omgevingsstructuur kunnen worden ontleend. ${ }^{12}$ ) Daarbij dient men in de eerste plaats te denken aan een beschrijving van de omgeving in culturele termen:

- de materiële cultuur (technologie, economie);

- de sociale instituten (maatschappelijke organisatie, politieke structuur, scholingsgraad);

- de waardensystemen, die belangrijk kunnen verschillen o.a. onder invloed van religieuze tradities;

- de voor de verschillende culturen of subculturen geldende esthetische opvat. tingen, die van belang zijn voor de interpretatie van de symbolische betekenis van artistieke impressies, kleuren, etc:;

- de taal, vooral in verband met mogelijke idiomatische verschillen. ${ }^{13}$ )

Gedetailleerde kennis over de culturele structuur van een land is daarom van zo groot belang, omdat vanuit de cultuur de basis kan worden gevonden voor het onderkennen van die produkteigenschappen, die door alle consumenten belang. rijk worden geacht. Uiteraard zullen er binnen een cultuur tussen individuele consumenten verschillen in produktperceptie blijven bestaan. Daaruit vloeit dan de noodzaak voort om de markt te segmenteren. Daarbij zal men zich niet kunnen beperken tot de meer traditionele segmentatiemethoden. Als aanvulling daarop dient te worden gezocht naar segmenten die ten aanzien van het produktperceptieproces een zekere mate van homogeniteit bezitten. „Benefit segmentation” als segmentatiemethode biedt daartoe de mogelijkheid.

\footnotetext{
12) Methodisch voegt multinationale marketing geen aspecten toe op het gebied van marktonderzoek Wel ontmoet men nieuwe problemen. Te denken valt aan de onderlinge vergelijkbaarheid van de secundaire gegevens en de moeilijkheden die men ontmoet bij het verzamelen van primaire gegevens (bijv. de vaststelling van de omvang van de steekproef. de opstelling van vragenlijsten, de bereidheid tot antwoorden van respondenten).

13) Een uitvoerige beschrijving van de culturele aspecien vindt men bij W. J. Keegan, Multinationd .Marketing.Management, Pren vice Hall. Englewood Cliffs, 1974, hfdst. 3 en bij P. R. Cateora, J. M. Hess, International Marketing Irwin, Homewood, llinois, 1975 , hfdst. 4.
} 
Voert men op deze wijze een segmentatie-analyse per land door, dan ontstaat een rijke bron aan informatie. Aan de hand van de relatieve omvang van de marktsegmenten kan worden vastgesteld, in hoeverre het gewenst is per land differentiaties aan te brengen in de marketing mix. Het is mogelijk om na te gaan of er segmenten zijn, die over de landsgrenzen heen een zekere mate van homogeniteit bezitten. Daardoor worden de realisatiemogelijkheden van een regio- of geocentrische benadering aangegeven. Van belang is voorts dat men aan de hand van het segment of de segmenten, die als doelgroep worden gekozen, kan komen tot een meer exacte schatting van het marktpotentieel. Betrekt men bovendien omgevingsvariabelen als de concurrentiestructuur, de door de overheid verleende speelruimte etc. in de beschouwing, dan kunnen uitspraken worden gedaan over het marktaandeelpotentieel.

De definitieve beslissing tot het bewerken van een nieuwe markt kan echter nimmer gebaseerd zijn op een analyse, die zich beperkt tot de vraagbepalende factoren. Ook de kostenaspecten zullen in aanmerking moeten worden genomen. Daarbij dient niet in eerste instantie te worden gedacht aan een vergelijking van opbrengsten en kosten per land, doch voor de organisatie als geheel. Naar onze opvatting dient in dit verband het begrip verwachte differentiële winst te worden gehanteerd. Daaronder verstaan wij het verschil tussen de geschatte winst, die een organisatie gedurende een bepaalde periode kan behalen bij uitbreiding van de marketingactiviteiten naar een nieuw land en de winst die verwacht zou mogen worden zonder deze uitbreiding.

\section{De marketing mix bij multinationale marketing}

In de marketingtheorie gaat men uit van de hypothese dat er klassen van instrumentele variabelen bestaan, die tezamen met de omgevingsvariabelen (de niet. beheersbare exogene variabelen) de uitkomsten van het marketingproces beïnvloeden. Aan de omgevingsvariabelen hebben wij uitvoerig aandacht besteed. ${ }^{14}$ ) Daarvoor zijn twee redenen aan te geven. In de eerste plaats is het zonder diepgaande kennis van de omgeving onmogelijk een concrete inhoud te geven aan de marketing mix. Voorts zijn het met name de omgevingsverschillen, die het onderscheid tussen mono en multinationale marketing rechtvaardigen.

Aangezien de nadruk dient te liggen op het aangeven van verschillen tussen multinationale en monomarketing, kunnen wij ons met betrekking tot de markt. instrumenten beperken tot het aangeven van een aantal specifieke problemen die men bij multinationale marketing kan ontmoeten. Wij zullen dat achtereenvolgens doen voor de produkt-, de prijs-, de reclame- en de distributiepolitiek. Daarna zullen wij kort stil staan bij de marketing mix.

\subsection{Produktpolitiek}

De mogelijke uitgangspunten die een organisatie kan kiezen bij het opstellen van een beleid met betrekking tot multinationale marketing, vinden wij terug bij de alternatieve strategieën die voor de afzonderlijke marktinstrumenten beschik. baar staan. Wat betreft de produktpolitiek kan men deze alternatieven aangeven

14) Wanneer wij in dit verband spreken over omgevingsvariabelen. doelen wij op variabelen uir de ..xterne" omgeving 
door twee uitersten te definiëren, namelijk een gestandaardiseerd of een gedifferentieerd produkt voor verschillende markten. Tussen deze twee extremen ligt een scala van mogelijkheden, waaruit een keuze kan worden gedaan.

Aan welk alternatief de voorkeur gegeven dient te worden, is niet in zijn algemeenheid aan te geven. Standaardisatie brengt belangrijke kostenvoordelen met zich, doch die voordelen dienen zorgvuldig afgewogen te worden tegen de mogelijke afzetverliezen die ontstaan, omdat onvoldoende rekening wordt gehouden met de door consumenten belangrijk geachte produkteigenschappen. Deze afweging wordt mogelijk gemaakt door de hantering van het begrip ver. wachte differentiële winst. Daarnaast kunnen omgevingsfactoren aanwezig zijn, die - onafhankelijk van het produktperceptieproces van consumenten - produktaanpassingen noodzakelijk maken. Te denken valt aan gebrekkige technische voorzieningen, die de organisatie kunnen verplichten produktsimplificaties aan te brengen. Of aan klimatologische factoren, die een modificatie in het produkt ver. gen.

Belangrijke problemen ten aanzien van de produktpolitiek kunnen ontstaan, in . dien de organisatie zich onvoldoende bewust is van het feit, dat het introduceren van een bestaand produkt op een buitenlandse markt strijdigheden in de traditionele consumptiegewoonten teweeg kan brengen. Robertson gaat er dan ook terecht vanuit, dat iedere introductie op buitenlandse markten gezien dient te worden als een nieuw produkt-introductie. ${ }^{15}$ ) Welke marketingstrategie daarbij moet worden gehanteerd, hangt af van de nieuwheidsgraad, d.w.z. de mate waarin door de introductie verstoringen in het bestaande consumptiepatroon worden veroorzaakt.

\subsection{Prijspolitiek}

Met betrekking tot het prijszettingsproces bij multinationale marketing is het zin vol een enkele opmerking te maken over een tweetal categorieën problemen die men ontmoet. De eerste categorie betreft problemen, die weliswaar niet uniek zijn voor multinationale marketing, doch die vanwege hun relevantie het vermelden waard zijn. Het gaat hier om de problematiek rond de vaststelling van de consumentenprijs. Een impliciete hypothese die veelvuldig wordt gehanteerd, is dat deze vaststelling is voorbehouden aan de producent. Wat betreft multinationale marketing vinden wij daarvan o.a. een voorbeeld bij de in de literatuur veelvuldig genoemde keuzemogelijkheid tussen standaardprijzen of gedifferentieerde prijzen, die producenten zouden hebben. De werkelijkheid leert echter, dat deze keuzevrijheid sterk beperkt kan zijn. In een groot aantal landen zijn de machtsver. houdingen binnen de bedrijfskolom sterk gewijzigd. Producenten worden niet geconfronteerd met een groot aantal kleine detaillisten, doch met een beperkt aan. tal grote detailhandelsorganisaties. Dit brengt mee dat voor producenten de speelruimte bij het prijszettingsproces sterk is gereduceerd.

Naast deze zowel voor mono als multinationale marketing geldende prijszet tingsproblematiek, ontmoet men bij multinationale marketing een aantal problemen, die zo al niet specifiek, dan toch - in vergelijking tot monomarketing - complexer zijn. Zo kunnen bij het bestaan van buitenlandse vestigingen met eigen produktiecentra kostprijsverschillen ontstaan, die het afwegen van centralisatie

\footnotetext{
15) T. S. Robertson, The New Product Diffusion Process, in B. A. Marvin (ed), American Marketing Association Proceedings, Chi. cago, 1969.
} 
rechtvaardigen. Er zullen verrekenprijzen tussen de buitenlandse vestigingen moeten worden vastgesteld. Bij het prijszettingsproces dient men rekening te houden met prijsfluctuaties in de munteenheden van de verschillende landen. Ten slotte zal er - binnen de beperkingen die van land tot land kunnen verschillen . zorg gedragen moeten worden voor:

- een onderlinge afstemming van de voor de verschillende landen geldende consumentenprijzen;

- een zo groot mogelijke mate van uniformiteit ten aanzien van de prijzen, die aan de distributiekanalen in rekening worden gebracht;

- een evenwichtige prijsopbouw van het assortiment per land en een afstem. ming van deze prijsopbouw tussen de landen.

\subsection{Reclamepolitiek}

Wanneer wij het als de taak van reclame zien om de consument te overtuigen van de aanwezigheid van de door hem relevant geachte eigenschappen en ,waarden" in het aangeboden produkt, dan kunnen er in dit uitgangspunt eigenlijk geen verschillen tussen mono en multinationale marketing bestaan. In beide gevallen zal de reclamepolitiek gebaseerd dienen te zijn op marktonderzoek, dat er op gericht is die relevante eigenschappen te ontdekken. Uit een dergelijk onderzoek zal naar voren komen in hoeverre er sprake is van homogeniteit binnen een land en over de landsgrenzen heen. Afhankelijk van de geconstateerde mate van homogeniteit zal een beslissing genomen kunnen worden over een univorme of een per land gedifferentieerde reclamecampagne.

Uniformiteit op zich is vanuit een aantal gezichtspunten aantrekkelijk. Er wor. den niet onbelangrijke besparingen door verkregen. Men denke slechts aan de hoge kosten die het differentiëren van televisie-spots naar land meebrengt. De planning en ook de controle op de uitvoering van de planning kan beter geschie. den. Voorts kan het toenemende internationale reisverkeer aanleiding zijn om te streven naar uniformiteit in reclamecampagnes.

In hoeverre uniformiteit is te realiseren, wordt in sterke mate bepaald door de aard van het produkt. Ook indien ten aanzien van het produktperceptieproces een hoge graad van homogeniteit bestaat, zal een volstrekte uniformiteit echter veelal onmogelijk zijn, o.a. als gevolg van media- en taalbeperkingen.

\subsection{Distributiepolitiek}

De distributieproblematiek bij multinationale marketing kent vele aspecten, die ieder voor zich voldoende relevantie bezitten om een uitvoerige behandeling te rechtvaardigen. Een gedetailleerde beschouwing zou ons in het kader van dit ar. tikel echter te ver voeren. Wij beperken ons daarom tot het globaal aanduiden van een drietal probleemvelden, te weten: de keuze van de distributiekanalen, de physieke distributie en het material management.

Ten aanzien van de keuze van de distributiekanalen ontmoet men bij de bewerking van meerdere markten twee belangrijke problemen. Er zal een beslissing moeten worden genomen over de kanalen, die binnen een bepaald land zullen worden gebruikt om de goederen bij de consument te brengen. Over het algemeen zal de keuzevrijheid, die de organisatie bezit bij het selecteren van deze distributiekanalen, vrij gering zijn. Omdat namelijk in vele gevallen de $20.80 \%$ regel 
geldigheid bezit, zal men voor het realiseren van een afzet van enige omvang wel genoodzaakt zijn bepaalde kanalen in te schakelen.

Daarnaast dient een keuze te worden gemaakt uit kanalen, die kunnen fungeren als distributieschakel tussen landen. Bij dit keuzeproces bezit de organisatie een grotere mate van vrijheid. Een aantal alternatieven hebben wij reeds genoemd, zoals directe en indirecte export, licentie, joint venture, etc. Aan welk alternatief de voorkeur wordt gegeven, zal in belangrijke mate afhangen van het beleid dat ten aanzien van multinationale marketing als uitgangspunt is gekozen.

Als tweede probleemveld hebben wij de physieke distributie genoemd. Het daarop betrekking hebbende management houdt zich enerzijds bezig met de regule. ring van de goederenstromen die beginnen aan het einde van het produktieproces en eindigen bij de consument, daarnaast met de gegevensstromen die nood. zakelijk zijn om de regulering van de goederenstromen zo efficiënt mogelijk te doen verlopen. Het gaat hier om beslissingen over de locatie van produktie- en/of verkoopvestigingen, centrale magazijnen, detailhandelspunten, etc. Er zal moeten worden vastgesteld waar en in welke omvang voorraden worden aangehouden, op welke wijze het intra- en internationale transport zal geschieden. De meeste van deze problemen zal men ook bij monomarketing ontmoeten, zij het dat de coördinatie bij multinationale marketing complexer van aard is. Met name de on. derlinge afstemming van de activiteiten in de verschillende landen doet een stuk aanvullende problematiek ontstaan.

Wij hebben ons in het bovenstaande beperkt tot een beschrijving van enkele problemen, die men bij de keuze van de distributiekanalen en de physieke pro. duktie ontmoet. In feite hebben wij daarbij een partiële benadering gevolgd. Het zal evenwel duidelijk zijn, dat beide probleemvelden in onderlinge samenhang dienen te worden beschouwd. Bovendien behoort een coördinatie tot stand te worden gebracht met een derde probleemgebied, namelijk material management. Daarbij gaat het om de activiteiten die erop gericht zijn de grondstoffen-en halffabrikaatstromen en de daarmee gepaard gaande gegevensstromen zo efficiënt mogelijk naar en door het produktieproces te voeren, alsmede om de werkzaam. heden die verricht worden om een zo efficiënt mogelijke benutting van het produktie-apparaat te bewerkstelligen.

\subsection{De marketing mix en de marketing planning}

Een beschouwing over multinationale marketing kan zich niet beperken tot het aanduiden van een aantal problemen, die zich ten aanzien van de afzonderlijke marktinstrumenten voordoen. Inzicht in deze deelproblematiek vormt weliswaar een essentiële voorwaarde voor het definiëren van een marketingbeleid, doch voor het vaststellen van de effectiviteit van de afzonderlijke instrumenten zullen wij de instrumenten in hun onderlinge samenhang moeten beschouwen of an. ders gesteld: de instrumenten moeten worden geintegreerd in de marketing mix.

De marketing mix problematiek bij multinationale marketing kent twee hoofd. aspecten. In de eerste plaats moet worden beslist over aanpassingen van de mix aan lokale omstandigheden. In hoeverre daarvan sprake zal zijn, is afhankelijk van meerdere factoren, zoals het door de organisatie gekozen uitgangspunt met be. trekking tot multinationale marketing, de aard van het produkt en het geheel van marktomstandigheden in een land. Het zullen met name omgevingsvariabelen zijn die de mate van autonomie bepalen, die de organisatie bezit bij het al dan 
niet doorvoeren van aanpassingen. De autonomiegraad zal over het algemeen ook verschillen per element van de marketing mix. Veelal bestaat de grootste vrij. heid ten aanzien van het produkt- en reclamebeleid. Deze twee instrumenten krij. gen in de literatuur over dit onderwerp dan ook de meeste aandacht. Keegan bijv. onderscheidt vijf mogelijke strategieën: een uniform reclame-en produktbeleid voor alle landen, een aanpassing in de reclame, een aanpassing in het produkt, een aanpassing in de reclame en het produkt, het introduceren van een geheel nieuw produkt. $\left.{ }^{16}\right)$ Deze strategieën vormen een duidelijke afspiegeling van de door ons geformuleerde uitgangspunten en kunnen slechts dienen als een voor. lopig startpunt voor de strategiebepaling bij multinationale marketing. De definitieve keuze van een strategie dient gebaseerd te zijn op gedetailleerd marktonderzoek per land.

Naast deze strategische beslissing over de aanpassing van de marketing mix, verdient een tweede beslissingsveld aandacht. Dat betreft de operationele beslissingen inzake de allocatie van middelen aan de marketing mix voor de verschil. lende landen. Een dergelijke toewijzing is slechts mogelijk indien er - per land gespecificeerd - inzicht bestaat in de effectiviteit van de individuele marktinstrumen ten. Die effectiviteit komt tot uitdrukking in de numerieke waarden van de responseparameters, die gevonden kunnen worden door bijv. toepassing van een post facto analyse. Men dient zich er evenwel van bewust te zijn, dat de numerieke waarde van de responseparameter van een individueel instrument afhankelijk is van meerdere factoren. De effectiviteit van een in een bepaald land gevoerde re. clame bijv. wordt niet alleen bepaald door het in reclame geïnvesteerde geldvo. lume, doch daarnaast door externe omgevingsvariabelen en variabelen die be. trekking hebben op de interne omgeving, zoals:

- de wijze waarop het creatieve en mediaselectie proces zijn uitgevoerd;

- het niveau van de andere elementen van de marketing mix. Een op zich goe. de reclamecampagne kan gepaard gaan met een lage waarde van de respon. separameter van reclame, bijv. doordat de numerieke distributie onvoldoende is geweest;

- de mate, waarin de marketingbeslissingen zijn gecoördineerd met de beslissingen uit andere functionele gebieden in de organisatie. Een onvoldoende afstemming van de marketing-, produktie- en financiële planning zal zijn weerslag hebben op de effectiviteit van de individuele marktinstrumenten. Dit onderling verweven zijn van de beslissingen in de verschillende functionele gebieden in een organisatie, brengt mede dat de coördinatie tussen deze beslis. singen een essentieel uitgangspunt vormt voor de marketingplanning. Multinationale marketing kent in dit opzicht een extra complicatie omdat de functionele gebieden zich in dat geval over meerdere landen uitstrekken, zodat de coördinatie grensoverschrijdend dient te geschieden. Dit brengt temeer de noodzaak mee deze coördinatie te benadrukken en wel om de organisatie in staat te stellen mo. gelijke oorzaken van afwijkingen tussen de verwachte en gerealiseerde effectivi. teit van de marktinstrumenten op te sporen, met name wanneer die oorzaken liggen buiten het gebied van de marketing mix.

16, W. J. Keegan, Five Strategies for Multinational Marketing, European Bustness, January, 1970, pp. 95.40. 


\section{Literatuur}

B. A. Bakker, Facetten van export marketing, Intermediair, 17 januari, 1975.

W. Burger, Intemational marketing planning, Intermediair, 27 september, 1975.

P. R. Cateora, J. M. Hess, International Marketing, Irwin, Inc., Homewood, Illinois, 1975.

Esomar, Marketing in a Changing World, Congres, 1972.

European Academy for Advanced Research in Marketing, Sixth Annual Workshop on Research in Marketing Session VII, Saarbrücken, 1977.

Exportstrategie in de tachtiger jaren, syllabus bij de conferentie ter gelegenheid van het zesde lustrum van Nijenrode, Breukelen, 1977.

A. P. van Gent, J. Bunt, B. A. Bakker, Europees marketing management, seminar, 1971.

W. J. Keegan, Multinational Marketing Management, Prentice Hall, Inc., Englewood Cliffs, New Jersey, 1974. P. Kotler, Marketing Management: Analysis, Planning and Controh Prentice Hall, Inc., Englewood Cliffs, New Jersey, 1972.

P. Kotler, A Generic Concept of Marketing, Joumal of Marketing, April, 1972.

H. J. Kuhlmeijer, The European Common Market: a New System of Production and Distribution in the Making, Michigan Business Review, March, 1971.

G. E. Miracle, G. S. Albaum, International Marketing Management, Irwin, Inc., Homewood, Illinois, 1970. Proceedings of the Indiana University D.B.A. Conference, Multinational Firm Strategies, Volume I and II, Blooming ton, Indiana, 1975.

Y. Wind, S. P. Douglas, H. V. Perlmutter, Guidelines for Developing International Marketing Strategies, Journal of Marketing, April, 1973.

H. B. Thorelli (ed.), International Marketing Strategy, Penguin Book, Harmondsworth, 1973. 